\title{
Apuleius' Treatment of Selected Progymnasmata in Florida
}

\author{
Natália Gachallová \\ (Masaryk University, Brno)
}

\begin{abstract}
The $2^{\text {nd }}$ century CE was a period of the rising prominence of epideictic rhetoric represented by travelling professional speakers who gave ex tempore speeches, not rarely, in front of mass audiences of various social scales. The traditional curriculum of the elite rhetorical education was based on the forms of practice called progymnasmata. These were a set of common, repeating rhetorical techniques and patterns gradually increasing in difficulty and exercising written composition as well as public performance. Students were supposed to create their own variations on given themes to embrace the basic rhetorical skills on which they could draw in the further stages of their education or professional career. Apuleius, one of the most prominent intellectuals of this time, made use of progymnasmata not only during his study years, but also later in his career of professional speaker. This is most apparent from his Florida, a collection of excerpted speeches performed mostly in Carthage. In this paper, I pursue to present the variety of Apuleius' approaches to these exercises with regards to different purposes of particular speeches. My goal is to assess the significance of progymnasmata in elite education as well as in intellectual discourse in terms of continuity and variation.
\end{abstract}

\section{Keywords}

progymnasmata; second sophistic; Apuleius; rhetorical education; Florida; intellectual discourse 
Before analyzing the particular excerpted speeches collected under the heading Florida and Apuleius' treatment of progymnasmata in these, few words have to be said about how these rhetorical exercises worked in Greco-Latin tradition. As the name itself suggests, these were fundamental rhetorical schemes including a set of narratives, figures, and sayings which belonged to a common Greco-Latin cultural property. As such, they were an inextricable part of the elite discourse not only in antiquity, but also throughout the whole Middle Ages, even up to the verge of Modernity. ${ }^{1}$ The origins of these techniques reach to the $4^{\text {th }}$ century BCE - the term progymnasma first appears in the handbook called Rhetorica ad Alexandrum which circulated under Aristotle's name but is now generally accepted to be a work of Anaximenes of Lampsacus. ${ }^{2}$

Most of the information we possess about progymnasmata comes from the preserved Greek treatises ranging from the $1^{\text {st }}$ century BCE to the $6^{\text {th }}$ century CE. The oldest extant treatise was written by Theon, however, earlier treatises which did not preserve certainly existed, as Theon mentions these in his work. Nevertheless, Theon's treatise is distinct from the other, with some variations in the sequence of the exercises, as well as its general purpose. Unlike the other treatises, it is not addressed to students but instructs teachers on how to implement each progymnasma into the curriculum, with emphasis put on their future practical use. From later periods we have treatises of Hermogenes, Aphthonius, and Nicolaus (the $2^{\text {nd }}, 4^{\text {th }}$, and $5^{\text {th }}$ centuries CE). ${ }^{3}$ Hermogenes' treatise has also been translated to Latin by Priscianus in the $6^{\text {th }}$ century CE under the title Praeexercitamina. Despite the long spans of time between the works, there is a great deal of unification and continuity among these. This confirms the uniform character of Greek and Roman rhetorical teaching.

Unfortunately, except for the above stated translation, we do not possess any Latin treatise exclusively dedicated to the use of progymnasmata. Still, there are plenty of accounts and indirect statements referring to these in the works of Roman authors, especially in Quintilian, Cicero, Suetonius, and in Pseudo-Cicero's Ad Herennium. There is no doubt that these rhetorical exercises were adopted mutatis mutandis in the Roman environment, in fact, these were usually first studied in Greek and only after that in Latin. ${ }^{4}$ Quintilian treats these in more detail as exercitationes primae in the second book of his Institutio oratoria (including the list of basic types like narrationes, opus destruendi confirmandique, laus, vituperatio, locus communis, thesis, legum laus et vituperatio), while he

1 The very same patterns can be traced e.g. in Christian hagiography, especially those of enkomion and topos. See Webb (2001: p. 312).

2 However, this also has been challenged; see Case (1996: p. 36). Webb (2001: p. 294, n. 20) suggests that the term might have just as well referred to preparatory exercises in general, not to progymnasmata in the sense they are treated here. The handbook seems to have had some impact on later rhetorical teaching, as well - Quintilian probably mentions it in his Institutio Oratoria (Inst. 3.4.9) when speaking about the seven species of declamation based on their particular goals (exhortatory, discouraging, praising, derogatory, accusing, defending, and critical). There is no doubt, however, that the unified system of progymnasmata was consolidated already in the Hellenistic times and implemented into Roman elite education. For a comprehensive analysis of this continuity, see Celentano (2011: pp. 358-359).

3 All Greek treatises are now newly available in the English translation of Kennedy (2003).

4 This was strongly recommended by Quintilian in Inst. 1.1.12: a sermone Graeco puerum incipere malo. 
also mentions the elementary stages of rhetorical education - curae quaedam dicendi primordia (including Aesopi fabellas ... sententiae quoque et chriae et aethologiae) in the very first book of Institutio. ${ }^{5}$ Some of the exercises are analyzed in Cicero's De inventione together with other rhetorical instruction regarding, for instance, the parts of speech and various types of orations. Furthermore, in Brutus, he recalls young years spent by training declamation when, as he claims, ab exercitationibus oratoriis nullus dies vacuus esset. Suetonius remarks on quaedam genera institutionum ad eloquentiam praeparandam among which he includes problemata, paraphrasis, allocutiones, ethologias et alia hoc genus. ${ }^{6}$ Although there are no extant Latin treatises on this topic, we possess the set of model exercises collected by Libanius ${ }^{7}$ in the $4^{\text {th }}$ century CE as well as several anonymous collections and a relatively high number of epitomes, commentaries, and scholia dealing with progymnasmata. ${ }^{8}$

The exercises were not designed only to practise students' art of written composition; they also prepared young aristocrats for the actual performance of the speech in front of very demanding audiences. Although structure and topics of the exercises were very much governed by the traditional model texts, they were, at the same time, subdued to constant re-working. In fact, variation and creative imitation were the key concepts of the rhetorical teaching, whereas students were encouraged to use their critical judgment to question or subvert the traditional concepts. ${ }^{9}$ The mastery lied in the transformation of a seemingly worn-up theme or pattern into an authentic and appealing shape. This, however, also implied that the level of skills attained largely depended on the quality of a particular teacher. Moreover, not all students must have completed the whole sequence, as suggested by Morgan (1998: pp. 199-203). It must also be mentioned, however, that progymnasmata may indeed have become mechanical and vacuous in the hands of bad teachers but this did not necessarily demean the usefulness and benefits of the whole system when applied in a proper way. The ancient scholars definitely had their reservations, too - both teachers of rhetoric like Theon or Quintilian obviously felt the urge to justify the practicability of such exercises and defend them against the criticism of those who regarded the endless reshaping of the texts as meaningless and sterile. For instance, Theon defends the uniformity of the practice as follows: ${ }^{10}$

The argument of opponents is that once something has been well said it cannot be done a second time, but those who say this are far from hitting on what is right. Thought is not moved by any one thing in only one way so as to express the idea (phantasia) that has occurred to it in a similar form, but it is stirred in a number of different ways...

5 Quint. Inst. 2.4 De primis apud rhetorem exercitationibus; 1.9.

6 Cic. Inv. Rhet. 1, Brut. 309-310; Suet. Gram. et rhet. 4.

7 For the most recent translation of Libanius' collection, see Gibson (2008).

8 For a detailed account of all source texts, see Heath (2002/2003).

9 E.g. students were supposed to compose psogoi on famous heroes.

10 Theon Prog. 62. The translation of Kennedy (2003: p. 6). 
Quintilian expresses the very same idea of flexibility, emphasizing the benefits of paraphrasing the works of others but also (and this is remarkable!) one's own works. He also stresses the importance of the exercises in later stages of one's career: ${ }^{11}$

Nam neque semper est desperandum aliquid illis quae dicta sunt melius posse reperiri, neque adeo ieiunam ac pauperem natura eloquentiam fecit ut una de re bene dici nisi semel non possit ... Nam si uno genere bene diceretur, fas erat existimari praeclusam nobis a prioribus viam; nunc vero innumerabiles sunt modi plurimaeque eodem viae ducunt ... nec aliena tantum transferre sed etiam nostra pluribus modis tractare proderit...

The key concept of the practice was continuity. This meant that the exercises were ordered in such a way that not a single one of them could be skipped or missed if one was to reach full rhetorical training, as each exercise was intertwined with the others. ${ }^{12}$

Such a rhetorical education was well unified throughout the Greco-Roman intellectual world and had a well thought-out structure which could be implemented in the curriculum from the early stages of education up to the most advanced levels of rhetorical education. The sequence usually started from the simplest exercises addressed to the beginners and gradually moved to the more complicated compositions requiring more advanced art of argumentation. Besides, the elements from the preceding exercises were constantly reiterated in the further stages of teaching. I state here the sequence according to the handbook of Aphthonius from the $4^{\text {th }}$ century CE, as it was definitely the most cited treatise, of which there are only slight variations in other preserved handbooks. All Greek terms are matched with their Latin equivalents:

\begin{tabular}{|c|c|c|}
\hline 1 & $\mu \tilde{v} \theta \mathrm{os}$ & fabula \\
\hline 2 & $\delta ı ́ \gamma \eta \mu \alpha$ & narratio \\
\hline 3 & 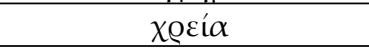 & chr(e)ia \\
\hline 4 & $\gamma \nu \omega \dot{\mu \eta}$ & proverbium \\
\hline 5 & $\dot{\alpha} v \alpha \sigma \kappa \varepsilon v \eta ́$ & refutatio \\
\hline 6 & $\kappa \alpha \tau \alpha \sigma \kappa \varepsilon v \eta ́$ & confirmatio \\
\hline 7 & 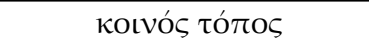 & locus communis \\
\hline 8 & $\dot{\varepsilon} \gamma \kappa \omega ́ \mu t о \nu$ & laus \\
\hline 9 & 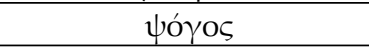 & vituperatio \\
\hline 10 & 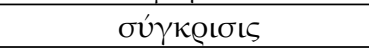 & comparatio \\
\hline 11 & 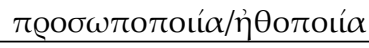 & prosopopoeia \\
\hline 12 & 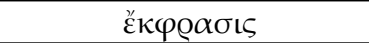 & descriptio \\
\hline 13 & $\theta \dot{\varepsilon} \sigma \iota \varsigma$ & thesis \\
\hline 14 & 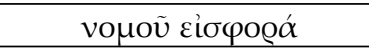 & legum laus/vituperatic \\
\hline
\end{tabular}

11 Quint. Inst. 10.5.5, 7, 9.

12 See Quint. Inst. 10.1.1: ... ita sunt inter se conexa et indiscreta omnia ut, si quid ex his defuerit, frustra sit in ceteris laboratum. 
Despite their conformity, each exercise, even those most elementary ones, was designed so as to be applicable on multiple levels and never for one purpose only. In the first stages of study, teachers used the platform similarly to today's language teaching students approached the texts as grammatical units trying to isolate, analyse, or convert the basic grammatical concepts like case, number, direct/indirect speech, or voice. Later on, students proceeded to a more rhetorical mode of thinking and saw the texts rather as the patterns open to re-working such as paraphrase, abbreviation, amplification, transliteration, or translation. The ideal outcome was to achieve facilitas which, in rhetorical terms, denoted an ability to use appropriate and effective language in each situation. This virtue is often advocated by Quintilian as the principle goal of each orator: ${ }^{13}$

Sed haec eloquendi praecepta, sicut cogitationi sunt necessaria, ita non satis ad vim dicendi valent nisi illis firma quaedam facilitas ... accesserit.

... ea quae in oratore maxima sunt imitabilia non sunt, ingenium, inventio, vis, facilitas et quidquid arte non traditur.

The very same virtue is stressed by Seneca in his Epistulae, when he praises certain orator named Fabianus: ${ }^{14}$

Fabianus, vir egregius et vita et scientia et, quod post ista est, eloquentia quoque, disputabat expedite magis quam concitate, ut posses dicere facilitatem esse illam, non celeritatem. Hanc ego in viro sapiente recipio, non exigo; ut oratio eius sine impedimento exeat, proferatur tamen malo quam profluat.

Importantly, the art of such a structured improvisation created not only skilled speakers but also critical listeners; thus, one of the essential goals of progymnasmata was to teach how to meet the expectations of the audience. Webb (2001: p. 291) pointedly remarks that the students used to recite their own compositions in front of their peers; this means that they were taught to establish a relationship with their audience from the very beginning of their training.

Apuleius' Florida, the central text of this paper, can be regarded a useful source in this context, too, even though it cannot be classified among rhetorical treatises or model rhetorical exercises. The $2^{\text {nd }}$ century CE Apuleius lived in was marked by increased significance of epideictic rhetoric which was one of the crucial characteristics of the Second Sophistic phenomenon. Anderson (1993: p. 47) even regards the exercises to be "one of the most characteristic cultural force in the formation of a sophist". This was the time when literature was more than ever viewed through the lens of rhetoric, while, at the same time, literary (especially poetic) features were often incorporated in speeches. It is

13 Quint. Inst. 10.1.1., 10.2.12. For an overview of Quintilian's teaching programme and the educational system he advocated, see Murphy (1990). It must also be stated that for Quintilian and his contemporaries, the idea of a well-spoken orator was inevitably bound with the idea of a good man. This is, nevertheless, a principle which is hard to embrace nowadays, as discussed by Fleming (2003: pp. 106-107). See also Hagaman (1986) who comments on the applicability of progymnasmata in today's teaching of rhetorical invention. 
beyond question that Apuleius can be considered one of the most successful ex tempore orators of his time, which is clear from both his life and his works. He was born around $123 \mathrm{CE}$ in the small provincial town of Madauros belonging to the province of Africa Proconsularis. ${ }^{15}$ His family was wealthy enough to provide him with the best education possible, which he himself documents in several places of his defence speech Apologia. He emphasizes that he is proud of his provincial origins: ${ }^{16}$

De patria mea uero, quod eam sitam Numidiae et Gaetuliae in ipso confinio mei $\langle s\rangle$ scriptis ostendi scis ... 'Seminumidam' et 'Semigaetulum';

and states that he is a son of an important and wealthy provincial official:

... in qua colonia patrem habui loco principis IIviralem cunctis honoribus perfunctum...;

... profiteor mihi ac fratri meo relictum a patre $H S X X^{17}$ paulo secus...

Notably, he boasts about getting the best education possible, first in Carthage to master the rudiments, then in Athens to proceed in higher stages of education, and, finally, possibly also in Rome to train himself in the field of judicial oratory where he seems to have gained some important contacts for his later career. Apart from these, he likes to stress his travels through the Mediterranean - he mentions his visits to Samos and Hieropolis in Phrygia, and intention to visit Alexandria, too. ${ }^{18}$

However, unlike many, Apuleius did not stay in Rome but, whatever the reason was, returned to North Africa and established a striking career here. He stresses this in many places, for instance, in Florida 16, where he proclaims himself to be a respected citizen of Carthage as well as some minor North African towns and a Platonic philosopher. He likewise refers to a statue built in his honour: ... statuam, quam mihi praesenti honeste postulastis et absenti benigne decrevistis..., and adds that he was erected statues in other cities, too: ... quae mihi ne in mediocribus quidem civitatibus umquam defuere ${ }^{19}$ It is also probable that he held the prestigious office of sacerdos provinciae, ${ }^{20}$ or a somewhat less prominent

15 I do not discuss here the aspects of Apuleius' life not completely relevant to the topic of this paper; for complete information on his life and works put in context, see Harrison (2000: pp. 1-38); Bradley (2012); and Lee, Finkelpearl, \& Graverini (2014).

16 Apul. Apol. 24.4, 24-25; 23.3-4.

17 Two millions sesterces were five times the equestrian census.

18 Studies in Carthage: Flor. 18.15, 18.36; studies in Athens: Flor. 20.4, 18.15; cf. Apol. 73.2; legal career in Rome: Flor. 17.4; travelling to Samos: Flor. 15.6; visiting Hieropolis De Mundo 17. Cf. Apul. Flor. 20.4: Ego et alias creterras Athenis bibi: poeticae commentam, geometriae limpidam, musicae dulcem, dialecticae austerulam, iam vero universae philosophiae inexplebilem scilicet et nectaream. See also Apul. Flor. 15, where the idea of a well-travelled sophist is accentuated, too.

19 See Apul. Flor. 16.25, 46. In Madauros, a statue base has been found with an inscription: <phi>losopho $\langle P l>$ atonico $<M a>$ daurenses cives ornamento suo (ILAlg 2115). If we identify the Platonic philosopher inscribed on the base with Apuleius, his accounts in Florida do not seem so exaggerated.

20 The title was originally flamen Augusti but during Trajan's reign it started to be called sacerdos provinciae (only a formal change); see Fishwick (2002: p. 188). 
office of sacerdos Aesculapii. ${ }^{21}$ This is mentioned in Florida, as well: ... sacerdotii summum mihi honorem Carthaginis adesse...; and is later documented also by Augustine. ${ }^{22}$ It is worth noting that several other sophists held this office, too, e.g. Favorinus or Scopelian, so it may have served as a post usually held by prominent intellectuals. ${ }^{23}$ Apart from his well-known extant works like Metamorphoses, Apologia, Florida, or De deo Socratis, we know that he also wrote a large amount of works of an impressively extensive variety of topics and genres including poetry, philosophical dialogues, technical treatises, collections of maxims, etc. ${ }^{24}$

But most of the information we possess about Apuleius' life and career come predominantly from two sources: Apologia, his defence speech performed at the court of Sabratha, and the Florida collection. The latter contains most of Apuleian word forms and figures occurring nowhere else and provides us with many accounts of Carthaginian public life. Thus, Florida collection is an obvious choice also when it comes to progymnasmata. Most, if not all, of the 23 speeches excerpted in the collection were performed in front of the Carthaginian audience during the 160s when Apuleius seemed to have had a prominent position in the intellectual life of the city, i.e. certainly after Apologia and probably before the publication of his novel Metamorphoses. ${ }^{25}$ The length and content of the fragments is very uneven - diverse themes are covered; some of the fragments are just short notes, while others appear to retain the length of a full speech.

There has been much discussion over the character and purpose of the collection which seems to have sprung especially from the fact that the actual collection we possess today is very probably not the same as the one published in Apuleius' times. ${ }^{26}$ At first glance, the extant fragments might make an impression that they were really meant to provide a sort of model texts for students of rhetoric including most of rhetorical forms. This is also suggested by the analogous structure of the collection, where the fragments covering similar topics are put next to each other with longer and shorter fragments alternating. In addition, almost every fragment may be seen as an elaboration of some progymnasma. This fits well with Theon's recommendation to teachers in his treatise to use works of respected authors followed by particular examples of works suitable for different purposes: ${ }^{27}$

21 Harrison (2000: p. 8); Sandy (1997: p. 8) infers that Apuleius' accounts in Florida (16.38; 18.38) refer to the priesthood of Aesculapius but accepts also Augustine's account of the office of sacerdos provinciae (August. Ep. 138.19). Lee (2005: p. 6) sums up the main arguments; contra Rives (1994: pp. 273 ff.) who assumes that Augustine wrongly identified the unspecified office Apuleius speaks of as sacerdos provinciae, arguing that Augustine did not know much more about Apuleius that we do today and may have been influenced by Apuleius' legendary reputation. He also points out that in Augustus' times there already was a decline of pagan cults, but not so of the imperial cult. To decide among these is impossible with the amount of evidence we possess but I am inclined to believe the first option or the possibility that he held both offices.

22 Apul. Flor. 16.38; August. Epist. 138.19.

23 Favorinus: see Philostr. VS 1.8.490; Scopelian: see Ibid. 1.21.515.

24 For the full account of his lost or fragmented works, see Harrison (2000: pp. 14-36).

25 For the chronology of Apuleius' works with regards to Florida, see Lee (2005: pp. 5-6).

26 For the discussion of various theories about the nature of Florida, see Opeku (1974: pp. 18-20) with whom I agree also on the matter of the original v. later excerption. However, I do not agree with his statement that the speeches were addressed to a less educated audience (Opeku 1974: pp. 22, 30). 
First of all, the teacher should collect good examples of each exercise from ancient prose works and assign them to the young to be learned by heart...

The model texts chosen by the teacher were memorized by students to provide them with a set of elegant expressions, figures, and rules of composition, they could always draw out from the treasury of their mind when needed. Quintilian, too, comments on the advantages of memorizing texts for the sake of rhetorical training: ${ }^{28}$

Nam et exercebitur acrius memoria aliena complectendo quam sua, et qui erunt in difficiliore huius laboris genere uersati sine molestia quae ipsi composuerint iam familiaria animo suo adfigent, et adsuescent optimis, semperque habebunt intra se quod imitentur, et iam non sentientes formam orationis illam quam mente penitus acceperint expriment. Abundabunt autem copia verborum optimorum et compositione ac figuris iam non quaesitis sed sponte et ex reposito velut thesauro se offerentibus.

These principles are quite well applicable to the text of Florida, too. On the other hand, when one digs deeper to the fragments, it stands out clearly that the original speeches had a different purpose than solely to instruct students of rhetoric. It will be shown that they served rather to promote Apuleius' own ideas on language, style, and, especially on the relationship of rhetoric and philosophy, as well as to advertise his own paideia. Although Florida can certainly be classified as a work of epideictic oratory (as for its choice of topics and the use of poetic rhetorical figures), it should not mislead us to belittle it as a work whose single purpose was rhetorical decoration and display. Additionally, Lee (2005: p. 23) rightly notes that "not all rhetorical theorists agreed that epideictic had no greater function than entertainment" and stresses the practical aspects of epideictic oratory. When it comes to Florida, it is clear that at least some of the speeches were performed at a particular occasion or for a particular audience and that these had at least some impact on the civic life of Carthage. ${ }^{29}$ The controversy between the first impression of a didactic text and the social and cultural implications it conveys is caused by the different aims of different collectors - first, of Apuleius himself or someone of his cultural milieu; second, of a later editor, perhaps a teacher striving to collect the examples of a good practice, as recommended by Theon. ${ }^{30}$

Acknowledging these, my intention is to approach the text as a personal insight into the mind of a prominent virtuoso speaker rather than a collection of mere rhetorical exercises. Therefore, the following analysis of the particular selected progymnasmata and their application in the particular fragments of the Florida collection cannot do without going beyond the superficial level. I will demonstrate the fact through the fragments 14 , 20 , and 15 consecutively.

28 Quint. Inst. 2.7.3-4.

29 See the three so-called proconsular speeches: Apul. Flor. 8, 9, and 17.

30 See also Harrison (2000: pp. 134-135) who rightly points out that the focus of the collection, as we posses it, is rather of someone interested in education, not of a sophistic speaker wanting to show off his knowledge. 
Florida 14 is constructed around the two anecdotes on the Cynic philosopher Crates. The first one conveys a famous maxim transcribed into Latin as Crates Cratetem manumittit, whose Greek equivalent has been preserved in the two centuries later Carmen de virtutibus of Gregorius of Nazianzus, the theologian and archbishop of Constantinople. ${ }^{31}$ The relevant passage reads as follows: ${ }^{2}$

Haec atque hoc genus alia partim cum audiret a Diogene Crates, alia ipse sibimet suggereret, denique in forum exsilit, rem familiarem abicit velut onus stercoris magis labori quam usui, dein coetu facto maximum exclamat: "Crates" inquit "Cratetem manumittit": et exinde non modo solus, verum nudus et liber omnium, quoad vixit, beate vixit.

The topic evidently goes well in line with the general interest of Second Sophistic in the stories of Greek past. Rhetorically speaking, it can be classified as a typical example of a chreia, i.e. a brief anecdote usually conveying a moral message and connected to a famous figure from the distant Greek past. ${ }^{33}$ In rhetorical handbooks, it is mostly put third in the sequence, only in Theon's treatise it is the very first progymnasma that students encounter. It could be used both in the earlier stages of education on a grammatical level, as well as in later stages as a platform for the more advanced techniques of elaboration. Apuleius elaborates on it altogether four times in Florida: twice in connection with famous Greek philosophers (namely Hellenistic Cynic Crates together with pre-Socratic Thales, as well as Protagoras and his pupil Euathlus), once when speaking about a famous musician Antigenidas living in the times of Alexander the Great, and once in relation with a renowned physician of the $2^{\text {nd }}-1^{\text {st }}$ cent. BCE named Asclepiades.

After this, Apuleius continues with a more extensive re-narration of a well-known story of Crates marrying Hipparche, a girl who abandoned her rich parents and household and went to live with the unattractive and poor Crates in the streets of Athens: ${ }^{34}$

\footnotetext{
Adeoque eius cupiebatur, ut virgo nobilis spretis iunioribus ac ditioribus procis, ultronea eum sibi optaverit. Cumque interscapulum Crates retexisset, quod erat aucto gibbere, peram cum baculo et pallium humi posuisset eamque supellectilem sibi esse puellae profiteretur eamque formam, quam viderat: proinde sedulo consuleret, ne post querela eam caperet; enimvero Hipparche condicionem accipit. Iam dudum sibi provisum satis et satis consultum respondit, neque ditiorem maritum neque formonsiorem uspiam gentium posse invenire; proinde duceret quo liberet.
}

There was clearly a general interest in this topic in Apuleius' times, as we can see from multiple narratives referring to Crates and the Cynics, e.g. in Plutarch, or Atheneaus. ${ }^{35}$

31 Greg. Naz., Migne, Patrologia Graeca 37, 696.

32 Apul. Flor. 14.1-2.

33 For the detailed account of the popularity of the themes of distant Greek past in the Second Sophistic, see Bowie (1970).

34 Apul. Flor. 2-5.

35 The standard source of information on Crates and the Cynicism seems to have been Plutarch's biography of this philosopher which, unfortunately, has not preserved - see Julian the Apostate's Or. 6.200b; see also 
Even though Apuleius' fondness of this historical figure might have been influenced by the Middle Platonist ideas he advocated, the occurrence of Crates in his work might have simply been motivated by the fact that he was very often used as an example in rhetorical training. Besides, Apuleius endorses another popular aspect of this story - the bawdiness of Cynics transgressing moral boundaries which were usually centred either around the figure of Crates, or, more frequently, of Diogenes of Sinope. This can be seen, for instance, in Diogenes Laertius' account of Diogenes' shameless behaviour in public: ${ }^{36}$

\begin{abstract}
Someone took him [Diogenes] into a magnificent house and warned him not to expectorate, whereupon having cleared his throat he discharged the phlegm into the man's face, being unable, he said, to find a meaner receptacle... When behaving indecently in the marketplace, he wished it were as easy to relieve hunger by rubbing an empty stomach. Seeing a youth starting off to dine with satraps, he dragged him off, took him to his friends and bade them keep strict watch over him. When a youth effeminately attired put a question to him, he declined to answer unless he pulled up his robe and showed whether he was man or woman...
\end{abstract}

Nevertheless, Apuleius does not only blindly apply the rules of composition he was taught at school but adjusts it to his own purposes. In the first place, Apuleius does not make much of Theon's strict condemn of the use of shameful chreiai for rhetorical purposes, in fact, he deliberately chooses the most scandalous version of Crates and Hipparche's marriage story - consummation of the marriage in public - with details occurring in no other author: ${ }^{37}$

Duxit Cynicus in porticum; ibidem, in loco celebri, coram luce clarissima accubuit, coramque virginem imminuisset paratam pari constantia, ni Zeno procinctu palliastri circumstantis coronae obtutum magistri in secreto defendisset.

What is more, Apuleius' choice of words reveals a great deal of playfulness and irony. The Stoic concept of constantia is turned upside-down: the self-consistency when it comes to physical needs and the innocence of emotions (parallel to Greek $\varepsilon \dot{v} \pi \dot{\alpha} \theta \varepsilon \iota \alpha$ ) the term advocates is here used for the newlyweds' rational decision to consummate their marriage in public. Such a reversal of serious matters into a bawdy talk is, of course, exercised in a much greater extent in Metamorphoses but the Florida collection seems to foreshadow some basic concepts later applied in the novel. ${ }^{38}$

Apuleius does not only advocate his liking for the Cynic philosophers, he also manipulates the two abovementioned narratives so as to convey a broader moral message. The underlying philosophical notion is that one can obtain freedom only by rejecting all

\title{
Ath. $158 \mathrm{a}-\mathrm{d}$.
}

36 D. L. 6.32; 46; see also 6.85-93. For easier understanding, the works of the authors writing in Greek are always stated in English translations. See the translation in Hicks (1925: Vol. II, pp. 33-35).

37 Apul. Flor. 14.6. Cf. Theon Prog. 104.

38 See, for instance, Apuleius' elaboration of the Florida 15 statue ekphrasis in Apul. Met. 2.4 (see note 67), or Apuleius' depiction of carnal issues in Flor.14 and throughout the whole novel Metamorphoses. 
wealth. This might be a recollection of Apuleius' self-defence speech Apologia in which he tries hard to present himself as a philosopher not seeking luxuries. The merits of poverty are praised here against the accusations of his adversaries, whereas the very same figure of Crates is used as an example: ${ }^{39}$

Proinde gratum habui, cum ad contumeliam diceretis rem familiarem mihi peram et baculum fuisse... Crates, inquam, si quid credis, Aemiliane, vir domi inter Thebanos proceres dives et nobilis amore huius habitus, quem mihi obiectas, rem familiarem largam et uberem populo donavit, multis servis a sese remotis solitatem delegit, arbores plurimas et frugiferas prae uno baculo sprevit, villas ornatissimas una perula mutavit.

The language used in Apologia is very similar to that of Florida, e.g. the references to pera and baculum as the typical attributes of a true philosopher. Thus, it seems plausible that the purpose of both passages is the same - to present oneself as equal to the famous philosopher in terms of reticence.

There is yet another layer to the story, namely the question of the compatibility of marriage and philosophy. In this, Apuleius draws on a popular topic of moral philosophy - the idea of кvvo $\alpha \mu$ i $\alpha$ which was notably discussed in Musonius Rufus' discourse on whether marriage is a handicap for the pursuit of philosophy. Let us have a look at Musonius' account of the story:40

Crates, although homeless and completely without property or possessions, was nevertheless married; furthermore, not having a shelter of his own, he spent his days and nights in the public porticoes of Athens together with his wife...

The motif of wealth rejection as the principal idea of the Cynics is echoed in fragment 22 of Florida, where Crates is pictured as Hercules. ${ }^{41}$ This even made the earlier editors believe that the two fragments were originally the two parts of the same speech. ${ }^{42}$ It is highly probable that Apuleius worked with the same material in both speeches. Lee (2005: p. 133) even sees Florida 14 as an anticipation of later Metamorphoses when it comes to Crates' bodily functions. The echoing and re-working of one's own other writings is, in general, something Apuleius is very fond of.

There seems to be some logical continuation with the previous fragment 13 which is concerned about the place of philosophy and rhetoric in society, as well as the inseparability of the two. The key concept proposed in this fragment is that rhetoric

39 Apul. Apol. 22.1-3.

40 Muson. 14.4.

41 The analogy was a locus communis of the Second Sophistic starting already in the Hellenistic period. Cf. Plut. Quaest. conv. 2.1.6; Muson. De Vit. Aer. Al. 8; and D. L. 6.86. The idea was that just like Hercules freed the world of monsters, Crates did the same with exaggerated emotions. Freeing oneself of unnecessary things is also expressed by the verb manumittere in the afore-stated maxim.

42 See G. E. Enhorstius' edition from 1621. This is, however, not a completely refuted idea even nowadays, see Harrison (2000: p. 129). 
is inevitably bound to the cultivation of virtue, whereas one cannot pursue philosophy without being able to speak well (there is no oratio without ratio and vice-versa). ${ }^{43}$ However, the ordering of the fragments could be the work of a later excerptor with a different aim; therefore, this remains a mere assumption.

Another fragment constructed on a progymnasma, but conveying a deeper message, is fragment 20. In this case, there is even a higher level of elaboration, as Apuleius makes use of more than one type of progymnasma at once - he incorporates gnome and enkomion. Gnome, or maxim, is very similar to chreia in that it conveys a universal declarative message either recommending something or, conversely, condemning something. This similarity puts it among the very first progymmnasmata in the sequence, very close to chreia. The two are sometimes even completely blurred into a single exercise. However, unlike chreia, it never describes actions nor does it usually include the author of the saying. All focus is put on the statement itself, which is much more confident and less open to discussion than chreia. Gnome also appears in Florida 2, where Apuleius discusses a saying of Socrates to defend rhetoric's indispensability for philosophy. ${ }^{44}$ As for the rhetorical exercise named enkomion, its composition required more advanced skills than that of chreia or gnome; accordingly, it was usually put somewhere in the middle of the sequence. The system of displaying one's qualities was very standardized. A praise usually started with the external aspects including good origin, family, education, wealth, reputation, sometimes even a good way of dying. After that, one was supposed to mention person's physical qualities like good health, strength, or beauty. Enkomia usually concluded with the ethical aspects of one's life, i.e. the actions which benefited others and the state or the person's pioneering role in something. Apuleius uses the form of enkomion altogether in four fragments. Three of these are the so-called proconsular speeches: fragment 8 is a laudation of an unnamed Carthaginian proconsul, fragment 9 praises another Carthaginian proconsul Severianus together with his son Honorinus, and fragment 17 applauds proconsul Scipio Orfitus.

Fragment 20, the fourth fragment containing enkomion, however, deviates from the abovementioned ones in that it is not connected to a particular occasion nor does it praise any local political figure. It loosely draws on the previous fragment and starts with a statement of "a wise man" (sapiens vir) on drinking wine: ${ }^{45}$

Sapientis viri super mensam celebre dictum est: "Prima", inquit, "creterra ad sitim pertinet, secunda ad hilaritatem, tertia ad voluptatem, quarta ad insaniam." Verum enimvero Musarum creterra versa vice quanto crebrior quantoque meracior, tanto propior ad animi sanitatem.

43 Apul. Flor. 13.3: Sed enim philosophi et oratio tempore iugis est et auditu venerabilis et intellectu utilis et modo omnicana. Cf. Apul. De deo Soc. 5: homines ratione gaudentes, oratione pollentes; and De dog. Plat. 1.14: homini promptuarium potius rectae rationis et suavissimae orationis datum est. The two words are used again in Flor. 18.5 in a different context (convenientium ratio et dicentis oratio). See also Cic. Off. 1.50: [universae generis humani societatis] ... autem vinculum est ratio et oratio...

44 See the previous note.

45 Apul. Flor. 20.1-2. Interestingly, Musae appear here both as patrons of literary genres (carmina, dialogi, hymni, modi, historiae, satirae) and of studying (litterator, grammaticus, rhetor). 
Although the author of the saying is not mentioned by name, we know that the maxim was traditionally attributed to Anacharsis, a legendary Scythian prince who lived among Greeks in the 6th century BCE and observed their customs to challenge their perception of the world. Harrison (2000: p. 126) supposes that his name is not mentioned by Apuleius because the Carthaginian audience was not acquainted with the sage; however, I suppose that the opposite is just as much plausible, i.e. the maxim and its author were so widespread that Apuleius found it unnecessary to cite his source. Anacharsis was traditionally regarded one of the Seven Sages and, in Hellenistic times, he became a kind of a medium through which moral and ethical concepts were conveyed. ${ }^{46}$ In the time of Second Sophistic, he appears as a prototype of vir sapiens, whereas the emphasis is put on his outspokenness, which well agrees with the importance of rhetoric in this time. Apuleius' choice of historical figure is, no doubt, deliberate, as it seems that Anacharsis was seen as a kind of "wise man at a table" drinking wine. ${ }^{47}$ Lucian of Samosata dedicates two of his dialogues to him: Scytha and Anacharsis; in these, he usually performs as an observer and student of Greek customs: ${ }^{48}$

\begin{abstract}
[Anacharsis:]"Well, Solon, why did I come all the way from Scythia, why did I make the long stormy passage of the Euxine, but to learn the laws of Greece, observe your customs, and work out the best constitution? That was why I chose you of all Athenians for my friend and host; I had heard of you; I had been told you were a legislator, you had devised the most admirable customs, introduced institutions of great excellence, and in fact built up what you call a constitution. Before all things, then, teach me; make me your pupil. Nothing would please me more than to sit by your side without bit or sup for as long as you could hold out, and listen open-mouthed to what you have to say of constitution and laws."
\end{abstract}

Diogenes Laertius, on the other hand, treats him traditionally as one of the Seven Sages and even concludes with the very same gnome on wine-cups used by Apuleius: ${ }^{49}$

\begin{abstract}
Anacharsis the Scythian was the son of Gnurus and brother of Caduidas, king of Scythia. His mother was a Greek, and for that reason he spoke both languages. He wrote on the institutions of the Greeks and the Scythians, dealing with simplicity of life and military matters, a poem of 800 lines. So outspoken was he that he furnished occasion for a proverb, "To talk like a Scythian." ... It was a saying of his that the vine bore three kinds of grapes: the first of pleasure, the next of intoxication, and the third of disgust.
\end{abstract}

However, unlike Diogenes, Apuleius does not only paraphrase the maxim, but also contrasts it with the educational process: ${ }^{50}$

46 This applies especially for Cynic philosophers and the so-called Letters of Anacharsis. One of these Cynic diatribes was even translated by Cicero in his Tusc. 5.90.

47 See Opeku (1974: p. 389) who points out two passages from Athenaeus where Anacharsis serves as a personification of popular wisdom at a drinking party: Ath. 10.437, 445.

48 Luc. Anach. 14. See the translation of Fowler \& Fowler (1905: Vol. III, p. 195).

49 D. L. 1.8.101/103. See the translation in Hicks (1925: Vol. I, pp. 105-107).

50 Apul. Flor. 20.3. 
Prima creterra litteratoris rudimento eximit, secunda grammatici doctrina instruit, tertia rhetoris eloquentia armat. Hactenus a plerisque potatur.

The Anacharsis' maxim is reflected in a tripartite division of education provided by litterator, grammaticus, and, finally, rhetor. This technique reminds us of the aforementioned treatises on progymnasmata, in which the composition of contrast is a very frequently recommended technique. ${ }^{51}$ The continuity with the previous fragment is preserved again, as both Florida 19 and 20 are framed by the topic of wine, the former mentioning the medical use of wine, the latter using the wine-cups metaphor. Here Apuleius contrasts the wine-cups which lead to insanity to the cups of knowledge, which, on the contrary, lead to wisdom. In this, he speaks of himself and his own path to wisdom, the climax of which is the study of philosophy: ${ }^{52}$

Ego et alias creterras Athenis bibi: poeticae comptam, geometriae limpidam, musicae dulcem, dialecticae austerulam, iam vero universae philosophiae inexplebilem scilicet et nectaream.

By this, he stresses his own versatility in the noblest areas of human wisdom, while reminding his audience of his studies in Athens. The versatility in many fields of scholarly interest was one of the crucial ideals of sophistic orators - Philostratus, the biographer of some $2^{\text {nd }}$ century CE sophists, even appreciates it as the biggest mastery of all. He starts his praise of Dio of Prusa as follows: ${ }^{53}$

I do not know what one ought to call him, such was his excellence in all departments; for, as the proverb says, he was "a horn of Amaltheia".

This was, no doubt, an ideal that Apuleius looked up to and strived to be praised for. Moreover, by putting philosophy at the climax of his list, Apuleius clearly demonstrates that he appreciates philosophy the most and wants to be treated as a philosopher. ${ }^{54}$

In the next part of the speech, he proceeds with particular examples of famous figures from the past and their areas of study only to conclude that he himself encompassed all of these: ${ }^{55}$

Canit enim Empedocles carmina, Plato dialogos, Socrates hymnos, Epicharmus modos, Xenophon historias, Crates satiras: Apuleius vester haec omnia novemque Musas pari studio colit, maiore scilicet voluntate quam facultate...

51 See the edition of Kennedy (2003) recommending the use of contrast in: chreia Theon Prog. 4.10, Hermog. Prog. 7-10; topos Hermog. Prog. 32-33; enkomion Aphth. 36; thesis Aphth. 51; ethopoiia Nicol. Prog. 66.

52 Apul. Flor. 20.4. See also note 14.

53 Philostr. VS 487.

54 See note 15 .

55 Apul. Flor. 20.5-6. 
This part, in which Apuleius emphasizes the universal nature of his literary versatility and compares it to that of famous intellectuals, is often pointedly called laudes Apulei and it is indeed laudatio sui ipsius in all the aspects important for an ex tempore orator. A similar strategy, though due to different reasons, is applied in Apologia. Here Apuleius draws a parallel between himself and the famous figures from the past on the basis of the accusations of magical practices - the idea is that the wise men must often face such accusations because their knowledge is often misunderstood as supernatural powers: ${ }^{56}$

Verum haec ferme communi quodam errore imperitorum philosophis obiectantur, ut partim eorum qui corporum causas meras et simplicis rimantur irreligiosos putent eoque aiant deos abnuere, ut Anaxagoram et Leucippum et Democritum et Epicurum ceterosque rerum naturae patronos, partim autem, qui providentiam mundi curiosius vestigant et impensius deos celebrant, eos vero vulgo magos nominent, quasi facere etiam sciant quae sciant fieri... Gratulor igitur mihi, cum et ego tot ac tantis viris adnumeror.

In Florida 20, he does not omit an obligatory locus modestiae, when defending himself against potential detractors: ${ }^{57}$

... eoque propensius fortasse laudandus est, quod omnibus bonis in rebus conatus in laude, effectus in casu est, ita ut contra in maleficiis etiam cogitata scelera, non perfecta adhuc vindicantur, cruenta mente, pura manu. Ergo sicut ad poenam sufficit meditari punienda, sic et ad laudem satis est conari praedicanda.

He underlines that if he did not succeed completely in all the above-mentioned areas, he should be praised for his good intentions only. In this, he clearly leans on the Stoic conception of voluntas and its significance to moral responsibility. ${ }^{58}$ Apuleius' line of argumentation is that if the bad intentions can be punished even when there was no action, then the good will should be praised, too, even if it was not realised in deeds.

This self-praise is then elegantly transformed into a praise of the city, often called laudes Carthaginis: ${ }^{59}$

Quae autem maior laus aut certior, quam Carthagini benedicere, ubi tota civitas eruditissimi estis, penes quos omnem disciplinam pueri discunt, iuvenes ostentant, senes docent? Carthago provinciae nostrae magistra venerabilis, Carthago Africae Musa caelestis, Carthago Camena togatorum.

Neither here does Apuleius exclude himself from the praise - the expression Apuleius vester creates a sense of solidarity among the Carthaginian community of the pepaideumenoi,

56 Apul. Apol. 27.

57 Apul. Flor. 20.6-8.

58 See e.g. Cic. Fin. 3.32: ea, quae proficiscuntur a virtute, susceptione prima, non perfectione, recta sunt iudicanda; Sen. Ben. 5.4.2: tam gratus est quisque, quam voluit; and Sen. Constant. 7.4: omnia scelera etiam ante effectum operis ... perfecta sunt. 
or the educated ones, and Apuleius himself. ${ }^{60}$ To flatter Carthage, an impressive poetic tricolon is used praising its erudition and culture. A special emphasis is put on the Roman character of the province - the audience is addressed as togati, which may have referred merely to the local officials but also to the audience as a whole. Furthermore, Apuleius uses both Greek and Latin terms Musa and Camena when describing Carthage to stress not only his own bilingualism, but perhaps also the Greco-Latin bilingualism of the whole province, at least, when it comes to intellectual elite. Carthage as Africae Musa then points to the leading role of the city in the cultural cultivation of Africa Proconsularis. ${ }^{61}$

Florida 15, the last fragment discussed in this paper, is one of the longest fragments of the collection. ${ }^{62}$ It opens with two ekphraseis: first, the island of Samos, the native land of Pythagoras, is described; after that, there is a more elaborate description of the statue displayed in its temple of Juno: ${ }^{63}$

Samos Icario in mari modica insula est - exadversum Miletos - ad occidentem eius sita nec ab ea multo pelagi dispescitur; utramvis clementer navigantem dies alter in portu sistit. Ager frumento piger, aratro inritus, fecundior oliveto, nec vinitori nec holitori scalpitur. Ruratio omnis in sarculo ei surculo, quorum proventu magis fructuosa insula est quam frugifera. Ceterum et incolis frequens et hospitibus celebrata... ... inde ante aram Bathylli statua a Polycrate tyranno dicata, qua nihil videor effectius cognovisse; quidam Pythagorae eam falso existimant. Adulescens est visenda pulchritudine, crinibus a fronte parili separatu per malas remulsis, pone autem coma prolixior interlucentem cervicem scapularum finibus obumbrat; cervix suci plena, malae uberes, genae teretes, at medio mento lacullatur; eique prorsus citharoedicus status: ... laeva distantibus digitis nervos molitur, dextra psallentis gestu pulsabulum citharae admovet, ceu parata percutere, cum vox in cantico interquievit; quod interim canticum videtur ore tereti semihiantibus in conatu labellis eliquare.

The teachers of rhetoric describe ekphrasis as a vivid evocation of places, events, periods of time, or inanimate objects. In line with Apuleius' account, ekphraseis were typically composed on the works of visual art, i.e. statues, paintings, the works of craft, as well as on the items of everyday use, as e.g. the famous ekphrasis of the Cloak of Jason in the Argonautika written by Apollonius of Rhodes. ${ }^{64}$ The essential element of this form was to create the impression of wonder and amazement. ${ }^{65}$ This was closely tied to another typical feature of ekphrasis - the notion that the perfection of a work of art is,

60 This strategy is similar to Apuleius' appeal to his friend and fellow student Claudius Maximus in his Apologia.

61 Opeku (1974: p. 399) adds that this perhaps also points to the literary dominance of North African writers in the contemporary Roman world. For the relationship of Apuleius and Carthage, see Bradley (2012: pp. 126-146) who stresses, and perhaps overestimates, Apuleius' role in the process of North Africa's Romanization.

62 The fragment is probably addressed to the departing proconsul of the year $162 / 3 \mathrm{CE}, \mathrm{Q}$. Voconius Saxa Fidus, as suggested by the phrase ab tuis antecessoribus; see Lee (2005: p. 134).

63 Apul. Flor. 15.1-10.

64 A.R. $720-763$.

65 For the more detailed account of ekphrasis in terms of wonder, see Shaffer (1998: pp. $308 \mathrm{ff}$ ). 
in fact, based on the deception of senses. The language of ekphraseis usually points at this by referring in various ways to the illusory nature of the object described. Consequently, the goal of an ekphrasis was to imitate the perfection of a piece of art by the same deception of senses, i.e. to describe it in such a way that it seemed almost present before one's eyes.

Apuleius' description of the statue may remind us of other Second Sophistic compositions describing ancient works of art and is echoed especially in the two $3^{\text {rd }}$ century sophistic collections - the Eikones of Philostratus the Elder which describe the panel paintings in Neapolitan gallery and the Ekphraseis of Callistratus dedicated to bronze and silver sculptures. ${ }^{66}$ See, for instance, Callistratus' ekphrasis of Orpheus' statue: ${ }^{67}$

... there stood beside the Muses a statue of Orpheus, the son of Calliope, a statue most beautiful to look upon. For the bronze joined with art to give birth to beauty, indicating by the splendour of the body the musical nature of the soul... The hair was so luxuriant and so instinct with the spirit of life as to deceive the senses into thinking it was being tossed and shaken by gusts of wind... For the bronze even acted the part of strings and, being so modified as to imitate each separate note, it obediently carried out the deceit, almost indeed becoming vocal and producing the very sound of the notes... You could see the bronze taking on the shape of rivers flowing from their sources toward the singing, and a wave of the sea raising itself aloft for love of the song, and rocks being smitten with the sensation of music, and every plant in its season hastening from its usual abode towards the music of Orpheus; and though there was nothing that gave out a sound or roused the lyre's harmony, yet art made manifest in all the animals the emotions excited by their love of music, and cursed their pleasure to be visible in the bronze...

There is also a striking similarity between the abovementioned ekphraseis and Apuleius' own famous description of Actaeon's statue in his novel Metamorphoses: ${ }^{68}$

... Ecce lapis Parius in Dianam factus tenet libratam totius loci medietatem, signum perfecte luculentum...; his oculi minantur, aures rigent, nares hiant, ora saeviunt, et sicunde de proximo latratus ingruerit, eum putabis de faucibus lapidis exire, et in quo summum specimen operae fabrilis egregius ille signifex prodidit, sublatis canibus in pectus arduis pedes imi resistunt, currunt priores... Sub extrema saxi margine poma et uvae faberrime politae dependent, quas ars aemula naturae veritati similes explicuit. Putes ad cibum inde quaedam, cum mustulentus autumnus maturum colorem adflaverit, posse decerpi, et si fontem, qui deae vestigio discurrens in lenem vibratur undam, pronus aspexeris, credes illos ut rure pendentes racemos inter cetera veritatis nec agitationis officio carere..

The phrases like putes, credes, or videtur well agree with the principal goal of this rhetorical form, i.e. to make the reader or the audience feel as if the described work of art were really present at the place. In Callistratus, too, the deceiving nature of an exquisite piece of art is stressed throughout the whole description. In this way, the visual

66 Both were published in the Loeb edition of Fairbanks (1931).

67 Callistr. Stat. 7. See the translation of Fairbanks (1931: pp. 401-403).

68 Apul. Met. 2.4. It is worth mentioning that this passage is Apuleius' own edition not inspired by the Greek epitome. 
effect of the sculpture is challenged by language. This concept is probably most explicitly discussed by Lucian in his Imagines, where the literary form stands higher than any plastic art and is the only one able to combine all aspects of the described object in a harmonious way: ${ }^{69}$

... let us put our portraits together, the statue that you modelled of her body and the pictures that I painted of her soul; let us blend them all into one, put it down in a book ... it would at least prove more enduring than the works Apelles and Parrhasius and Polygnotus ... inasmuch as it is not made of wood and wax and colours but portrayed with inspirations from the Muses; and this will be found the most accurate kind of portrait, since it simultaneously discloses beauty of body and nobility of soul.

In Apuleius, this is closely related to the idea of rhetoric as a figurative art of representation next to the visual arts and the tension between the two. As Lee (2005: p. 88) puts it, language mirrors life; therefore, it is confronted with the same challenges as visual arts - it is subject to imitation and mistreatment. This reminds us of Florida 7, in which Apuleius mentions the edict of Alexander the Great limiting the number of artists permitted to represent him followed by a wish that a similar edict is produced when it comes to philosophy in order to get rid of false charlatans of knowledge: ${ }^{70}$

Quod utinam pari exemplo philosophiae edictum valeret, ne qui imaginem eius temere adsimularet, uti pauci boni artifices, idem probe eruditi omnifariam sapientiae studium contemplarent, neu rudes, sordidi, imperiti pallio tenus philosophos imitarentur.

The significance of language for philosophy is stressed also in Apuleius' De dogmate Platonis. Apuleius describes Plato as someone who, thanks to his reason and eloquence, adapted, combined, and reshaped the very scattered and unpolished Socrates' ideas into a unified philosophy: ${ }^{71}$

Nam quamvis de diversis officinis haec ei essent philosophiae membra suscepta, naturalis a Pythagoreis, de Eleaticis rationalis atque moralis ex ipso Socratis fonte, unum tamen ex omnibus et quasi proprii partus corpus effecit; et, cum principes harum familiarum inpolitas sententias et inchoatas auditoribus tradidissent, eas hic, cum ratione limando tum ad orationis augustae honestissimam speciem induendo, perfectas atque etiam admirabiles fecit.

69 Luc. Im. 23. See also Ibid. 5: ... if from now on we give Master Eloquence a free hand ... and allow him to adapt, combine, and unite them ... retaining at the same time that composite effect and the variety. See the translation of Harmon (1925: Vol. IV, pp. 267, 295).

70 Apul. Flor. 7.9-10. The topic of unworthy imitation is echoed in fragment 9, which starts with Apuleius address towards his "invisores". Language is again described as a process of representation reminiscent of visual arts and is also judged according to similar criteria; see e.g. the verbs of artistic consideration like examinatis, pensiculatis, or comparatis.

71 Apul. De dog. Plat. 1.3. 
In addition to these, Apuleius does not forget to mention that he himself visited the island and saw the statue with his own eyes. According to Sandy (1997: p. 171), and I regard it plausible, this stress on autopsy is used by Apuleius to differentiate himself from his rivals and to establish his own public image of a well-travelled educated man. The inner logic of the continuation is based on the fact that, according to Apuleius, some regard this statue a representation of Pythagoras, which he rejects immediately with another short elaboration of a progymnasma, this time an anaskeue: ${ }^{72}$

Verum haec quidem statua esto cuiuspiam puberum, qui Polycrati tyranno dilectus Anacreonteum amicitiae gratia cantilat. Ceterum multum abest Pythagorae philosophi statuam esse; et natu Samius et pulchritudine adprime insignis et psallendi musicaeque omnis multo doctissimus ac ferme id aevi, quo Polycrates Samum potiebatur, sed haudquaquam philosophus tyranno dilectus est.

However, the two descriptions in fragment 15 are, in fact, incorporated as a sort of a springboard for further investigation of the role of Pythagoras' ideas in Plato's teaching. This shift is introduced by one of the versions of Pythagoras' travelling for wisdom, namely his travels to India where he is said to have been inspired by the practices of Brahmani, or the so-called gymnosophists ("naked wise men"). ${ }^{73}$ From this, Apuleius proceeds to the discussion of Pythagorean elements in Plato's philosophy crowned by the statement Plato noster pythagorissat. This is conforming to the $2^{\text {nd }}$ century and Apuleius' own interest in Middle Platonism ${ }^{74}$ as well as to the general interest of Second Sophistic in the topics of mystery, secrecy, and revelation. The notion is nothing new: already Aristotle drew a connection between these two sages, while Cicero took it over later in his Disputationes Tusculanae. ${ }^{75}$ Perhaps surprisingly for a professional speaker, Apuleius seems to appreciate the training of silence as the first step towards wisdom among Pythagoras' pupils: ${ }^{.76}$

... primus philosophiae nuncupator et conditor, nihil prius discipulos suos docuit quam tacere, primaque apud eum meditatio sapienti futuro linguam omnem coercere verbaque, quae volantia poetae appellant, ea verba detractis pinnis intra murum candentium dentium premere. Prorsus, inquam, hoc erat primum sapientiae rudimentum, meditari condiscere, loquitari dediscere.

Hence, he advocates the idea that a good orator knows when there is an appropriate time to speak as well as when to prefer silence. The verb loquitari as opposed to meditari seems to be reminiscent of Apuleius' previous discussion of silly talking and empty imitation in fragments 12 and 13, which share the common platform comparing human and

72 Apul. Flor. 15.11-12.

73 See also Plutarch's account of these in his Alex. 64-65 which is echoed in the Florida fragments 6 and 7 dealing with India, as well as with Alexander the Great.

74 See Apul. Apol. 4.6 and De dog. Plat. 1.3.

75 Arist. Metaph. 987a 29 ff.; Cic. Fin. 5.87, Rep. 1.16: [Platon] ... leporem Socraticum subtilitatemque sermonis cum obscuritate Pythagorae et cum illa plurimarum artium gravitate contexuit.

76 Apul. Flor. 15.22-24. 
birds' voices. Furthermore, Pythagoras' idea of meditatio as silent contemplation was very different from the rhetorical use of the word in the sense of practise or rehearsal, i.e. rhetorical training. ${ }^{77}$ Therefore, I suppose that this passage may be one of the provocations addressed to Apuleius' opponents, implying that they do not know when to keep their mouths shut. Conversely, it is pointed out that Apuleius, unlike others, does possess this skill. ${ }^{78}$ This seems even more plausible, when compared to Florida 17, where Apuleius attacks his potential rivals by alluding to their excessive use of words motivated by greed. Interestingly, also this passage is followed by a comparison of human and animal voices. Needless to say, Apuleius, according to his own words, is far from making such a mistake: ${ }^{79}$

Viderint, quibus mos est oggerere, se et otiosis praesidibus, ut impatientia linguae commendationem ingenii quaerant et adfectata amicitiae vestrae specie glorientur. Utrumque eius a me, Scipio Orfite, longe abest.

The point of this fragment clearly is Apuleius' self-promotion and self-classification as one of the "initiates" of Plato and a well-educated cosmopolite man. Analogously to Apuleius vester used in his praise of Carthage, Apuleius chooses the pronoun noster when referring to Plato; thus, a close link is drawn between himself and the famous philosopher. Simultaneously, his personal liking for exotic cults and rites is supported by the historical connection between Platonic philosophy and the eastern wisdom.

To conclude, almost each fragment of Florida can be analysed with similar results, since almost all speech fragments are constructed on some progymnasma or a combination of more progymnasmata. However, despite the fact that the tone of the fragments is usually given by a conventional topic elaborated through some of these exercises, the real purpose and message of the fragments have to be searched for between lines. Apuleius uses the common rhetorical exercises as a tool for conveying his own ideas on language, style, philosophy, and rhetoric. The unifying theme of the fragments is, no doubt, Apuleius' emphasis on the role of language in human wisdom and on the importance of language to philosophy with regard to living a moral life. This has to do both with the general tendency of his age as well as with his own conceit of rhetoric and philosophy intertwined formulated in the phrase philosophi ratio et oratio. ${ }^{80}$ The atmosphere of the fragments is clearly Middle Platonist with a flavour of the topics popular in Second Sophistic like the stories of great Greek past, exotic lands, and habits.

Another facet of the collection is the demonstration of Apuleius' paideia, rhetorical finesse, and literary versatility. This is done either by direct references to his studies or particular knowledge, or indirectly by the use of "unlooked for and unexpected words"

77 Both Quintilian (Inst. 10.1) and Gellius (NA 20.50.2) commonly use the term meditationes when speaking of rhetorical exercises. See also Lee (2005: p. 144).

78 Cf. the concept of facilitas discussed above.

79 Apul. Flor. 17.1.

80 See Apul. Flor. 13.3. 
- the principle advocated by M. Cornelius Fronto a generation earlier. ${ }^{81}$ Besides, it cannot be omitted that at least some of the speeches were addressed to a particular audience or pronounced at a particular occasion; therefore, the sociological aspect of such rhetorical performances should not be underestimated. To sum up, it would be unfair to regard Florida a collection of mere rhetorical trifles with no deeper message. The fact that they usually spring from or are built around some rhetorical exercise, does not determine their significance or impact - one has to keep in mind that any intellectual discourse was necessarily imbued in one way or another with the basic principles taught by progymnasmata.

\section{Bibliography}

Anderson, G. (1993). The Second Sophistic. A Cultural Phenomenon in the Roman Empire. London New York: Routledge.

Bowie, E. L. (1970). Greeks and Their Past in the Second Sophistic. Past EF Present, 46, 3-41.

Bradley, K. (2012). Apuleius and Antonine Rome: Historical Essays. Toronto - Buffalo - London: University of Toronto Press.

Burgess, T. Ch. (1902). Epideictic Literature (Studies in Classical Philology). Chicago: The University of Chicago Press.

Butler, H. E. (1920). The Institutio Oratoria of Quintilian in Four Volumes (Loeb Classical Library). Cambridge, Mass.: Harvard University Press.

Case, T. (1996). Aristotle. In W. Wians (Ed.), Aristotle's Philosophical Development. Problems and Prospects (pp. 1-40). Lanham: Rowman \& Littlefield.

Celentano, M. S. (2011). Oratorical Exercises from the Rhetoric to Alexander to the Institutio oratoria: Continuity and Change. Rhetorica: A Journal of the History of Rhetoric, 29(3), 357-365.

Corbeill, A. (2001). Education in the Roman Republic: Creating Traditions. In Y. L. Too (Ed.), Education in Greek and Roman Antiquity (pp. 261-287). Leiden: Brill.

Fairbanks, A. (Transl.). (1931). Philostratus the Elder, Imagines. Philostratus the Younger, Imagines. Callistratus, Descriptions (Loeb Classical Library). London: Heinemann.

Fishwick, D. (2002). The Imperial Cult in the Latin West, Volume III: Provincial Cult. Part 2: The Provincial Priesthood. Leiden: Brill.

Fleming, J. D. (2003). The Very Idea of a Progymnasmata. Rhetoric Review, 22(2), 105-120.

Fowler, H. W., \& Fowler, F. G. (1905). The Works of Lucian of Samosata. Oxford: Clarendon Press.

Gibson, C. A. (2008). Libanius' Progymnasmata: Model Exercises in Greek Prose Composition and Rhetoric. Leiden - Boston: Brill.

Gleason, M. (1995). Making Men: Sophists and Self-Presentation in Ancient Rome. Princeton: Princeton University Press.

81 See Fronto Ep. Marc. Caes. 4.3.3 (57.16 van den Hout, 1.1 Haines): insperata atque inopinata verba. Cf. Quint. Inst. 8 prooem. 31. 
Goldhill, S. (2009). Rhetoric and Second Sophistic. In E. Gunderson (Ed.), Cambridge Companion to Ancient Rhetoric (pp. 228-241). Cambridge: Cambridge University Press.

Groningen, B. A. van (1965). General Literary Tendencies in the Second Century A. D. Mnemosyne, 18(1), 41-56.

Hagaman, J. (1986). Modern Use of the Progymnasmata in Teaching Rhetorical Invention. Rhetoric Review, 5(1), 22-29.

Haines, C. R. (1919). The Correspondence of Marcus Cornelius Fronto (2 Vols.). London: Heinemann. Harmon, A. M. (Transl.). (1925, 1931, 1961). Lucian (Vol. IV; pp. 255-295). London: William Heinemann Ltd.; Cambridge: Harvard University Press.

Harrison, S. (2000). Apuleius. A Latin Sophist. Oxford - New York: Oxford University Press.

Harrison, S., Hilton, J. L., \& Hunink, V. (2001). Apuleius. Rhetorical Works. Oxford: Oxford University Press.

Heath, M. (2002/2003). Theon and the History of the Progymnasmata. Greek and Roman Byzantine Studies, 43, 129-160.

Hicks, R. D. (1925). Diogenes Laertius. Lives of Eminent Philosophers (2 Vols.; Loeb Classical Library). Cambridge, Mass.: Harvard University Press.

Hout, M. P. J. van den (1988). M. Cornelius Fronto: Epistulae. Leipzig: Teubner.

Hout, M. P. J. van den (1999). A Commentary on the Letters of M. Cornelius Fronto. Leiden: Brill.

Hunink, V. (1997). Apuleius of Madauros: Pro Se de Magia (2 Vols.). Amsterdam: J. C. Gieben.

Hunink, V. (2001). Apuleius of Madauros: Florida. Edited with a Commentary. Amsterdam: Gieben.

Kaster, R. A. (1983). Notes on 'Primary' and 'Secondary' Schools in Late Antiquity. Transactions and Proceedings of the American Philological Association, 113, 323-346.

Kennedy, G. A. (2003). Progymnasmata: Greek Textbooks of Prose Composition and Rhetoric. Atlanta: Society of Biblical Literature.

Korenjak, M. (2000). Publikum und Redner. Ihre Interaktion in der sophistischen Rhetorik der Kaiserzeit. München: C. H. Beck Verlag.

Lee, B. T. (2005). Apuleius' Florida: A Commentary. Berlin: Walter de Gruyter.

Lee, B. J., Finkelpearl, E., \& Graverini, L. (2014). Apuleius and Africa. New York - London: Routledge.

Morgan, T. (1998). Literate Education in the Hellenistic and Roman Worlds. Cambridge: Cambridge University Press.

Murphy, J. J. (1990). Roman Writing Instruction as Described by Quintilian. In J. J. Murphy (Ed.), A Short History of Writing Instruction: From Ancient Greece to Twentieth Century America (pp. 36-76). Davis, CA: Hermagoras.

Opeku, F. (1974). A Commentary with Introduction on the Florida of Apuleius (Doctoral dissertation). University of London (retrieved 22.09.2017 from https:/ qmro.qmul.ac.uk/xmlui/bitstream/ handle/123456789/1550/OPEKUCommentaryWith1974.pdf?sequence=1).

Putnam, E. J. (1909). Lucian the Sophist. Classical Philology, 4(2), 162-177.

Rives, A. J. (1994). The Priesthood of Apuleius. The American Journal of Philology, 115(2), 273-290.

Sandy, G. (1997). Greek World of Apuleius. Leiden: Brill.

Shaffer, D. (1998). Ekphrasis and the Rhetoric of Viewing in Philostratus' Imaginary Museum. Philosophy E Rhetoric, 31(4), 303-316. 
Webb, R. (2001). The Progymnasmata as Practice. In Y. L. Too (Ed.), Education in Greek and Roman Antiquity (pp. 289-316). Leiden: Brill.

Whitmarsh, T. (2005). The Second Sophistic. Oxford - New York: Oxford University Press.

Mgr. Natália Gachallová / 261004@mail.muni.cz

Department of Classical Studies

Masaryk University, Faculty of Arts

Arna Nováka 1, 60200 Brno, Czech Republic 
